\title{
LIBERALISM, PUBLIC MORALITY, AND CONSTITUTIONAL LAW: PROLEGOMENON TO A THEORY OF THE CONSTITUTIONAL RIGHT TO PRIVACY
}

\author{
David A.J. Richards*
}

I

\section{INTRODUCTION}

The legitimacy of the criminal law rests on the conception of public morality that a society regards as justly enforceable. ${ }^{1}$ This conception of public morality has two components: a theory of morally wrong acts and a theory of culpability attributing blame for such acts. ${ }^{2}$ It also defines a corresponding theory of the moral virtues that the society praises and the moral vices that it condemns, because moral virtue is, at least in part, the effective desire and capacity to be free of culpable wrongdoing, and moral vice is the propensity to be guilty of such wrongdoing. ${ }^{3}$ Societies differ in their conceptions of public morality, defining the moral universe of wrongdoing, culpability, and vice in correspondingly different ways.

What is the conception of enforceable public morality appropriate in a liberal society? John Stuart Mill gave the classic liberal answer to this question in the terms of his harm principle. ${ }^{4}$ According to this principle, subject to background duties of justice and fair contribution, the coercive power of the state can only be imposed for acts causing harms to other persons. Harms to self do not suffice. ${ }^{5}$ Mill justified the harm principle in terms of a doctrinal utilitarianism that is, in fact, inconsistent with the stringent demands that the principle imposes on the proper scope of the

Copyright $(\mathcal{C} 1988$ by Law and Contemporary Problems

- Professor of Law, New York University School of Law; A.B. 1966, Harvard University; D. Phil. 1970, Oxford University; J.D. 1971, Harvard University; member, New York Bar.

This article profited from a generous research grant from the New York University School of Law Filomen D'Agostino and Max E. Greenberg Faculty Research Fund.

1. See The Expressive Function of Punishment, in J. Feinberg, Dorng and Deserving 95-118 (1970).

2. See, e.g., D. Richards, A Theory of ReASONS For ACTION 75-241 (1971).

3. See id. at $\mathbf{2 8 3 - 8 5}$

4. See J. Mill, On Liberty, in The Philosophy of John Stuart Mill 185, 187-203, 271-319 (M. Cohen ed. 1961).

5. Many liberals no longer agree with the stringent form of Mill's formulation of the harm principle, such as his prohibition of paternalistic arguments. See, e.g., H. HarT, LaW, LiberTy, and MORALITY 30-34 (1963). For a plausible contemporary restatement of Mill's harm principle, see J. Feinberg, HaRm to Others 1-27 (1984). 
criminal law. It often appears to be the case that the utilitarian goal of the greatest aggregate sum of pleasure over pain is better achieved by the tribal solidarity of collective social intolerance, which the harm principle clearly condemns. ${ }^{6}$ An alternative political theory is needed that explains how and why the harm principle intuitively identifies the constraints that liberalism imposes on the conception of enforceable public morality.

This article adopts the working premise that liberalism does indeed express a distinctive normative attitude to the public morality justly enforceable through the criminal law and takes American constitutional liberalism as a case study in the analysis of this distinctive public morality. Accordingly, this article seeks to clarify the liberal conception of enforceable public morality through reference to the internal struggles against alternative conceptions of enforceable public morality that distinctively mark the emergence of American constitutional liberalism in particular, and liberal political theory in general.

The nature of constitutional liberalism (reflected in both the theory and practice of both the United States Constitution of 1787-88 and the Bill of Rights of 1791) was a product of the Founders' rejection of the theories of virtue and vice as related to public morality assumed by classical republican tradition. ${ }^{7}$ The liberal conception of public morality can be best understood by contrasting it with the alternative view that it self-consciously rejected. With this purpose in mind, this article examines the nature of the rejection of the classical republican tradition, the correlative rejection of the perfectionist theories of virtue and vice as the political psychology of republicanism, and the alternative conception of a constitutional republic that this rejection made possible. In this way, this article will clarify the alternative conception of republican public morality that motivates this rejection, its philosophical roots in Lockean liberalism, and the principled constitutional rejection of established churches through which America institutionalized that liberalism. This approach responds to the need for a nonutilitarian basis for the harm principle through an alternative understanding of both the derivation and interpretation of the harm principle as a central principle of liberal constitutionalism. The argument also suggests reasons for skepticism about the contemporary revival of Aristotelian virtue theory. ${ }^{8}$

Finally, the approach proposed in this article casts interpretive light on one of the most controversial issues in American public law: the inference and elaboration of the constitutional right to privacy. This article illustrates

6. See D. Richards, Sex, Drugs, Death and the law: An Essay on Human Rights and Overcriminalization 2-7 (1982) [hereinafter Sex, Drugs, Death]; D. Richards, Toleration and The Constitution 237-42 (1986) [hereinafter D. Richards, Toleration].

7. For a general description of this tradition, see J. Pocock, The Machiavellan Moment (1975). For another argument that the Founders significantly rejected the classical republican tradition, see J. Diggins, The Lost Soul of American Politics 18-130 (1984); Diamond, Ethics and Politics: The American Way, in The Moral Foundations of the American Republic 75 (R. Horwitz 3d ed. 1986).

8. See generally A. MAcINTYRE, After Virtue (1981). 
that the constitutional right to privacy is the principled interpretive elaboration of a longstanding constitutional skepticism about state enforcement of certain conceptions of perfectionist public morality, a skepticism that framed the Founders' general approach to the framing of the Constitution. The article, therefore, suggests that it is profoundly ahistorical to regard the constitutional right to privacy as foreign to either the text, history, or political theory of the United States Constitution. To the contrary, the constitutional right to privacy corresponds to some of the most brilliant and innovative insights of the Founders about the political pathologies of faction that a well constructed republican constitution must address. Constitutional privacy was not foreign to the Founders' intent, and it is a mark of our debased public understanding of the Founders' project that the rhetoric of the Founders' intent has recently been so abusively used against the inference and elaboration of the constitutional right to privacy.

II

\section{The Rejection of Classical Republicanism}

From its inception, American constitutionalism has distinguished its republican aspirations from the classical democratic models of antiquity and the Renaissance, ${ }^{9}$ with their Aristotelian ${ }^{10}$ and Machiavellian ${ }^{11}$ foci on the actively engaged citizen-soldier.

The model classical society was one in which political participation was the central activity of civilized life. In Athens, this was made possible by a social structure based upon slavery and sexism. ${ }^{12}$ Correlatively, Athens proudly touted its regime of free speech as an aspect of the ultimate evaluative aim of democratic participation. ${ }^{13}$ Absent from this conception is any valorization of a legitimately private sphere immune from politics. Pericles bluntly made this point: "We do not say that a man who takes no interest in politics is a man who minds his own business; we say that he has no business here at all."14 Family life, for example, was contemptuously remitted to the morally inferior class of women, whose labor was given weight only insofar as it released men for public life. ${ }^{15}$ Work was for slaves, thus releasing citizens for civic life in the agora. ${ }^{16}$ Socratic individualism, including its uses of free speech, was not

9. See, e.g., The Federalist No. 10, at 61-65 (J. Madison) (J. Cooke ed. 1961). For extended comparisons, see J. ADAMS, A Defence of the Constitutions of Government of the United States of America, in 4 C. Adams, The Works of John Adams $472-492$ (1851) [hereinafter $A$ Defense]. For fuller examination, see D. Richards, Foundations of American Constitutionalism (forthcoming, 1989).

10. See, e.g., Aristotle, The Politics of Aristotle 92-110 (E. Barker trans. 1962).

11. See, e.g., Machiavelli, The Discourses 265-90 (L. Walker trans., B. Crick ed. 1970).

12. See generally Rahe, The Primacy of Politics in Ancient Greece, 89 AMerican Historical Review 265 (1984); M. Finley, Politics in the Ancient World 70-85 (1983); M. Finley, Democracy ANCIENT AND MOdern 15-38 (1985).

13. See Pericles' Funeral Oration, in Thucydides, History of the Peloponnesian War 147 (R. Warner trans. 1954).

14. Id.

15. See, e.g., ARistotle, supra note 10, at 8-38.

16. Id. at 9-17. For pertinent discussion of changing conceptions of work, see H. ARENDT, ThE Human Condition 136-137 (1959). 
only misunderstood by the political system, it was also ruthlessly persecuted for its individualistic moral conception which legitimated uses of free speech that were taken by the Athenian democracy to be impious and heretical, and thus worthy of death. ${ }^{17}$

Of course, the classical conception specifies an elaborate theory of democratically controlled collective political life. ${ }^{18}$ But that conceptionprecisely because of its emphasis on collective mass participation-identifies the moral aims of democracy with voting and participation, and their constitutive role in the flowering of such human excellences as civic generosity, military courage, heroism, and patriotism-in other words, the perfectionist virtues of Aristotelian ethics. ${ }^{19}$

Theories of normative ethics are commonly distinguished into teleological and deontological types. ${ }^{20}$ Teleological theories define "right" actions in terms of the tendency of those actions to result in the greatest net aggregate of goods over evils. Deontological theories are those that do not define right action in such terms. Perfectionist moral theory is a teleological theory that defines the relevant goods and evils in terms of the greatest exercise and display of talent, creativity, and general excellence, including artistic and intellectual performance, and military courage and prowess. Aristotle's perfectionism, like Nietzsche's, ${ }^{21}$ assumes that these qualities are unequally distributed, and thus justifies, as a matter of normative principle, both slavery and the subjugation of women ${ }^{22}$ as ways to realize perfectionist ends. For example, artists or patriotic men are relieved from having to do work that frustrates their capacity to realize the only goods of ultimate moral worth, namely, superior achievement of talent, creativity, and general excellence. ${ }^{23}$

Aristotelian perfectionism, thus understood, was fundamentally elitist, and perceived slavery and the subjugation of women as wholly natural, indeed morally required, ways to preserve the proper role of the talented elite. Classical republicanism assumed these perfectionist aims and thus viewed the extraordinary demands of classical republican participation as instrumental in the full flowering of human excellence. In particular, the moral theory of classical republicanism emphasized perfectionist heroism in the service of the ultimate unit of value, the polis, which defined the indispensable context for the fostering and display of the elitist human excellences. Democratic

17. Socrates makes precisely this predictive point about his own fate at the hands of his fellow Athenians in Plato, Gorgias 101-02 (T. Irwin trans. 1979).

18. See, M. Finley, Politics in the Ancient World, supra note 12, at 63-69.

19. See generally Aristotle, Nicomachean Ethics (M. Ostwald trans. 1962).

20. See J. Rawls, A Theory of Justice 25-27, 30 (1971).

21. For a fuller discussion, see D. Richards, supra note 2, at 116-17.

22. For a fuller discussion and relevant citations, see D. RichaRDs, supra note 2, at 117 .

23. Contemporary forms of perfectionist moral theory are not, of course, inevitably wedded to such conclusions. See generally V. Haksar, Equality, Liberty, and Perfectionism (1979); J. Raz, The Morality of FreEdom (1986). An alternative kind of teleological theory, namely, utilitarianism, identifies goods and evils in terms of pleasures and pains that are, in principle, more equally distributed among all sentient creatures than the excellences of Aristotelian perfectionism. See generally H. Sidgwick, The Methods of EThics (1962). 
participation was valued as the matrix for the exercise and display of these perfectionist virtues.

The classical republican conception lacks the ideal of self-government that motivates liberal democratic constitutionalism, and it is this difference that explains at least three of the reasons why the drafters of the 1787 Constitution rejected the classical republican conception. First, the drafters of the United States Constitution repudiated the mass democratic participation in government that was central to classical republicanism. Madison, with characteristic precision, denied the claim made by other Founders that the representative principle was completely unknown to classical democratic polities. ${ }^{24}$ Rather, he argued that

[t]he true distinction between these and the American Governments lies in the total exclusion of the people in their collective capacity from any share in the latter, and not in the total exclusion of representatives of the people, from the administration of the former. The distinction however thus qualified must be admitted to leave a most advantageous superiority in favor of the United States. But to ensure to this advantage its full effect, we must be careful not to separate it from the other advantage, of an extensive territory. ${ }^{25}$

Madison identified such mass assemblies with the mob rule that had discredited republicanism as an acceptable form of constitutional government:

In all very numerous assemblies, of whatever characters composed, passion never fails to wrest the sceptre from reason. Had every Athenian citizen been a Socrates, every Athenian assembly would still have been a mob. ${ }^{26}$

Accordingly, a properly designed republican constitution must, Madison argued, use the representative principle to preserve republican accountability, and also to structure democratic politics in legislative assemblies so as to better achieve the end of republican government, which Madison identified with "[j]ustice." 27 Madison's reference to the "extensive territory" of the United States echoes his earlier argument in No. 10 of The Federalist, that the representative principle operating over such a large territory and population would channel democratic politics in ways more likely to lead to certain substantive results like securing "the rights of other citizens, or . . . the permanent and aggregate interests of the community." 28

A second reason for the Founders' rejection of the classical republican conception was that they did not construe rights to vote for, and participate in, government as being the highest social values. Rather, they saw these rights as means to ensure that the state will respect individual rights and pursue the public good. Indeed, from this characteristically Lockean and

24. In his opening address to the Pennsylvania ratifying convention, James Wilson stated: "One fact, however, is certain, that the ancients had no idea of representation, that essential to every system of wise, good, and efficient government." See 2 M. JEnSen, The Documentary History of the Ratification of the Constitution 343 (1976).

25. The Federalist No. 63, at 428 (J. Madison) (J. Cooke ed. 1961)

26. The Federalist No. 55, at 374 (J. Madison) (J. Cooke ed. 1961)

27. The Federalist No. 51, at 352 (J. Madison) (J. Cooke ed. 1961).

28. The Federalist No. 10, at 57 (J. Madison) (J. Cooke ed. 1961) 
liberal perspective, voting rights are not themselves the ends of republican politics, but the means to independently specified ends. As such they may be defined, limited, and weighted in whatever ways are most likely to secure these ends (including, for example, the property qualifications common in American politics in 1787). ${ }^{29}$ Of course, from its beginning, American democratic constitutionalism has distributed the franchise more broadly than comparable democracies (for example, Great Britain ${ }^{30}$ ), and the progressive historical elaboration of constitutional principles (including the 15th, 19th, and 26th amendments) has expanded the scope of the democratic franchise still more broadly and more equitably (for example, reapportionment of voting power in accord with one person/one vote ${ }^{31}$ ). It is wholly consistent with the spirit of the American conception of voting rights that, as the maldistribution of voting rights is perceived to frustrate effective respect for equal rights under law and fair pursuit of the public good, the scope and distribution of such voting rights should in these ways be more fully and fairly extended in service of these goals.

The final reason for the drafters' rejection of classical republicanism was their deep distrust of the concept's perfectionist virtues of civic generosity and military heroism as the reigning political psychology of a well-functioning polity. Madison, for example, identified the political psychology of faction as a central evil of political life:

By a faction I understand a number of citizens, whether amounting to a majority or minority of the whole, who are united and actuated by some common impulse of passion, or of interest, adverse to the rights of other citizens, or to the permanent and aggregate interests of the community. ${ }^{32}$

He condemned classical republicanism for the uninhibited play it gave faction thus understood:

Such Democracies have ever been spectacles of turbulence and contention; have even been found incompatible with personal security, or the rights of property; and have in general been as short in their lives, as they have been violent in their deaths. Theoretic politicians, who have patronized this species of Government, have erroneously supposed, that by reducing mankind to a perfect equality in their political rights, they would, at the same time, be perfectly equalized and assimilated in their possessions, their opinions, and their passions. ${ }^{33}$

From this perspective, the perfectionist public morality of ancient Sparta-so admired by Rousseau ${ }^{34}$-expresses yet another form of faction, a thought John Adams put with characteristic bluntness:

29. See J. Pole, Political Representation in England and the Origins of the American Republic 25, 31, 36, 84, 136, 170, 208 (1966). See also W. Adams, The First American Constitutions 164, 196-217, 293-307 (R. Kimber \& R. Kimber trans. 1980).

30. This was attributable, at least in part, to the broader diffusion of property in the United States than Britain. See, e.g., J. Pole, supra note 29, at 205-06.

31. See generally Reynolds v. Sims, 377 U.S. 533, 555 (1964); Baker v. Carr, 369 U.S. 186 (1962).

32. The Federalist No. 10, supra note 9, at 57 (J. Madison).

33. Id. at 61-62.

34. See, e.g., Rousseau, Considerations on the Government of Poland, in Rousseau: Political WRITINGS 162-67 (F. Watkins trans. 1953). 
Separated from the rest of mankind, they lived together, destitute of all business, pleasure, and amusement, but war and politics, pride and ambition; . . as if fighting and intriguing, and not life and happiness, were the end of man and society; as if the love of one's country and of glory were amiable passions, when not limited by justice and general benevolence .... Human nature perished under this frigid system of national and family pride. ${ }^{35}$

The Founders thus perceived the perfectionism of classical republicanism as the key to the concept's political vices because they interpreted its parochial insularity as inconsistent with the fundamental values of their own republican project, namely, respect for rights and pursuit of the public good. For this reason, Madison, like Adams, argued that a well-designed constitutional democracy should achieve its ultimate ends without requiring all of its citizens to display the heroic virtues of classical republicanism. ${ }^{36}$

What, for the American Founders, were the ultimate ends of governance, and why were the theory and practice of classical republicanism inconsistent with the achievement of these ends? As we have seen, the Founders rejected various aspects of classical republicanism (ethical perfectionism, mass assemblies, rights of voting and participation as ultimate ends), because they regarded them as inconsistent with the ultimate ends of republican constitutionalism. The crucial point is that the Founders understood the purpose of their constructivist project to be the protection of the inalienable rights of the person. These are the rights that persons cannot surrender to the state and are rights against which the legitimacy of state power must accordingly be tested. The idea of such rights-so foreign to classical political theory-centered on concepts such as the inalienable right to conscience, the right of each person as a democratic equal to form, express, and revise personal ethical theories as an expression of his practical rationality and reasonableness. ${ }^{37}$

\section{III}

\section{LIBERALISM AND RESPECT FOR RIGHTS}

When the British philosopher, Richard Price, wrote in defense of the American Revolution and the emerging pattern of American constitutionalism, ${ }^{38}$ he identified four principal liberties for which the Americans fought: physical, moral, religious, and civil. He defined and explicated these liberties in the following striking terms:

By PHYSICAL LIBERTY I mean that principle of Spontaneity, or Self-determination, which constitutes us Agents; or which gives us a command over our actions, rendering

35. See C. AdAms, supra note 9 , at 554 .

36. See generally A. Lovejoy, Reflections on Human Nature (1961).

37. See, e.g., D. Richards, Toleration, supra note 6, at 85-102.

38. Pertinent texts include R. Price, Observations on the Nature of Civil Liberty, the Principles of Government, and the Justice and Policy of the War with America (1776); $R$. Price, Additional Observations on the Nature and Value of Civil Liberty, and the War with America (1777); R. Price, Observations on the Importance of the American Revolution (1785). Both Observations on the Nature of Civil Liberty and Additional Observations are reprinted in R. Price, Two Tracts on Civil Liberty the War with America and Finances of the Kingdom (Da Capo Press ed. 1972) [hereinafter R. Price, Two Tracts]. 
them properly ours, and not effects of the operation of any foreign cause.-MORAL LIBERTY is the power of following, in all circumstances, our sense of right and wrong; or of acting in conformity to our reflecting and moral principles, without being controuled by any contrary principles.-RELIGIOUS LIBERTY signifies the power of exercising, without molestation, that mode of religion which we think best; or of making the decisions of our own consciences respecting religious truth, the rule of our conduct, and not any of the decisions of our fellow-men.- In like manner; CIVIL LIBERTY is the power of a Civil Society or State to govern itself by its own discretion, or by laws of its own making, without being subject to the impositions of any power, in appointing and directing which the collective body of the people have no concern, and over which they have no controul.

It should be observed, that, according to these definitions of the different kinds of liberty, there is one general idea, that runs through them all; I mean, the idea of selfdirection, or self-government. ${ }^{39}$

The point is not that persons are asocial monads who form their identities out of nothing. Such would be a mistaken reading of liberalism. To the contrary, Locke, for example, assumed that social institutions, like language, frame the question of how to live, and are presuppositions of the liberal state. ${ }^{40}$ Liberalism arose when the traditional power of certain institutions (established churches, for example) over crucial areas of personal life was rejected on the ground of the political principle of liberty of conscience. The right to conscience, which encompasses Price's moral and religious liberties, was identified as a central paradigm of inalienable human rights ${ }^{41}$ because it protects the natural moral competence of each person, as a democratic equal, to make reasonable judgments about the basic personal and ethical values around which he organizes a theory of a well-lived life. This preserves choice among competing communities of belief. In Price's terms, the right to conscience secures essential powers of self-government or personal autonomy because it protects independent judgment in the formation, expression, and revision of basic evaluative beliefs about the value of life. ${ }^{42}$

The point at which liberal political theory departs most radically from classical republicanism is in its respect for and guarantee of the basic rights of the person, such as the right to conscience, and also in its preservation of an individual moral independence-itself often critical of the claims of state power. Therefore, a critical distance is maintained between state power and the individual, who is the ultimate repository of moral and political sovereignty. This is in contrast to classical republicanism and its celebration of the heroic virtue of service to the state. Skepticism of state power over questions of conscience first arose with the breakdown of religious and moral orthodoxy in the Reformation and the widespread literacy made possible by the printing press. The grounds for that skepticism derived from a larger

39. R. Price, Two Tracts, supra note 38, at 3-4.

40. See, e.g., J. Tully, A Discourse on Property: John Locke and His Adversaries 3-50 (1980).

41. See, e.g., Additional Observations on the Nature of Civil Liberty, in R. Price, Two Tracts, supra note 38 .

42. For a comparable argument that respect for rights secures a sort of sovereignty analogous to political sovereignty among nations, see J. Feinberg, Harm to Self 27-97 (1986). 
skepticism about traditional conceptions of authority in science, religion, ethics, and politics. ${ }^{43}$

\section{IV}

\section{Universal TOlERATION AND LibERTY NEUTRALITY}

When Locke 44 and Bayle ${ }^{45}$ stated their pathbreaking arguments for universal religious toleration (however cramped by contemporary standards since they excluded Catholics and atheists ${ }^{46}$ ), they focused on an incoherence in the traditional Augustinian argument for religious persecution. ${ }^{47}$ While Augustine defended respect for the integrated exercise of the rational capacity, belief, and desire of the human person, he also imputed to any dissenter from religious orthodoxy an irrational demonic fault in the will that, like insanity, called not for respect but for coercive intervention to protect others from injury and the agent from self-injury. ${ }^{48}$ The inference is not only wrong, but viciously circular. Augustine and his epigones ${ }^{49}$ took conventional standards of orthodox belief, to which they were committed, as the exclusive measure of all forms of reasonable belief and, on this ground, imputed to dissenters a lack of rational capacity of the sort that requires not respect but intervention. In effect, they read issues of rational and reasonable capacity through the prism of committed sectarian belief, and thus failed to accord any fair respect for the exercise of rational and reasonable capacity independent of such sectarian belief. ${ }^{50}$

The analysis of this political pathology in Locke and Bayle is piercing, focusing as it does on the elaboration of a familiar theme in seventeenthcentury moral thought ${ }^{51}$ : the ways in which the language of moral virtue was often a rhetorical mask for entrenched self-interest, sectarian bias, and the manipulative pride of power. Neither Locke nor Bayle was a moral skeptic 52

43. For a fuller discussion, see D. Richards, Toleration, supra note 6, at 67-128, 166-74.

44. See $6 \mathrm{~J}$. Locke, The Works of JohN Locke (1 l th ed. 1812) The sixth volume contains four letters concerning toleration.

45. See P. Bayle, Commentaire Philosophique sur ces paroles de Jesus Christ "Contrain-les dentree", in 2 Oeuvres Diverses de M. Pierre Bayle 257-560 (1727) [hereinafter Commentaire Philosophique]. For an English translation of Bayle's commentary, see P. LANG, Pierre Bayle's Philosophical Commentary: A Modern Translation and Critical Interpretation (P. Lang trans. 1987).

46. For Locke, see A Letter Concerning Toleration, being a translation of the Epistula de Tolerantia, in $6 \mathrm{~J}$. Locke, Works of John Locke, supra note 44, at 1, 45-47 [hereinafter A Letter Concerning Toleration]. For Bayle, see P. Bayle, Commentaire Philosophique, supra note 45, at 410-15 (Catholics), 431 (atheists).

47. See, e.g., Augustine, The Political Writings of St. Augustine 190-240 (H. Paolucci ed. $1962)$.

48. See texts cited in Augustine, The Political and Social Ideas of St. Augustine 205 (H. Deane ed. 1963), which make this point exactly.

49. See T. Aquinas, Summa Theologiae 89-91 (T. Gilby trans. 1974).

50. For a fuller discussion, see D. Richards, Toleration, supra note 6, at 85-98.

51. See generally A. Lovejoy, supra note 36 .

52. On Locke, see generally J. Colman, John Locke's Moral Philosophy (1983); on Bayle, see E. Labrousse, Bayle 70-71 (D. Potts trans. 1983). 
along the lines of Hobbes ${ }^{53}$ and Mandeville, ${ }^{54}$ and they therefore did not infer from such self-righteousness that there were no applicable standards of ethical justification independent of self-interest. To the contrary, their argument for universal toleration presumed political conditions that would allow the development of an ethic of equal respect uncorrupted by the moral tyranny of sectarian self-righteousness (including, for Locke, the unconscionable legitimation of political tyranny in the form of absolute monarchy ${ }^{55}$ ).

It is this perspective that explains the American Founders' rejection of classical republicanism as the operative political psychology of American constitutionalism. As discussed earlier, from the perspective of American constitutional thinkers like Madison and Adams, the elitist Aristotelian perfectionism of classical republicanism was a species of faction, highly insular and parochial. Thus, in Madison's terms, it was "adverse to the rights of other citizens, or to the permanent and aggregate interests of the community," 56 and it often acted, according to Adams, "as if the love of one's country and of glory were amiable passions, when not limited by justice and general benevolence." 57

For Madison, as for Adams, the motivating public morality of American republicanism was an ethic of equal respect, where public power was harnessed both to insure respect for the inalienable rights of persons and to pursue the public good. ${ }^{58}$ That egalitarian ethic, made possible by respect for each person's equal liberty of conscience, ${ }^{59}$ was, by definition, an ethic whose demands could be met by and reasonably justified to our common human nature. ${ }^{60}$ That ethic could, therefore, only impose burdens of civil duty that could be reasonably borne by all persons and justified to them as reasonable

53. See T. Hobbes, Leviathan 63-84 (M. Oakeshott ed. 1955). For pertinent commmentary, see D. Gauthier, The logic of Leviathan 1-26 (1969); G. Kavka, Hobbesian Moral. and Political Theory 29-82 (1986); L. Strauss, The Political Philosophy of Hobbes 108-28 (E. Sinclair trans. 1984).

54. See B. Mandeville, The Fable of the Bees (Phillip Harth ed. 1970). For pertinent commentary, see M. Goldsmith, Private Vices, Public Benefits: Bernard Mandeville's Social and Political. Thought 1-46 (1985).

55. See generally J. Locke, Two Treatises of Government (P. Laslett ed. 1960).

56. The Federalist No. 10, supra note 9, at 57 (J. Madison).

57. 4 C. Adams, The Works of John Adams, supra note 9 , at 554

58. For Madison, see The Federalist Nos. $10 \& 51$, at 56,347 ( J. Cooke ed. 1961); for John Adams, see 4 C. Adams, The Works of John Adams, supra note 9, at 318 ("[T]he end of government is the greatest happiness of the greatest number, saving at the same time the stipulated rights of all.").

59. Madison makes this point in his Memorial and Remonstrance. See, e.g., THE Mind of THE Founder 10-11 (M. Meyers ed. rev. ed. 1981). Jefferson made a similar point in his Bill for Establishing Religious Freedom, whose enactment Madison's Memorial and Remonstrance defends. See T. JEFFERSON, $A$ Bill for Establishing Religious Freedom, in 2 The PAPERs of Thomas JefFerson, 1777-1779, at 545 (J. Boyd ed. 1950). John Adams suggests a not dissimilar link in his $A$ Dissertation on the Canon and Feudal Law, in 3 C. Adams, The Works of John Adams 447-64 (1851). For a discussion of the link between Jefferson's and Madison's theory of anti-establishment and the unleashing of a republican public morality of equal respect, see generally Richards, Religion, Public Morality, and Constiutional Law, in NOMOS Yearbook on Religion, Morality, and the Law 152 (1988).

60. Cf. Scanlon, Contraclualism and Utilitarianism, in Utilitarianism AND Beyond 103-28 (A. Sen \& B. Williams eds. 1982). 
demands. The perfectionist elitism of classical republicanism imposed selfsacrificing ideals of heroic excellence well beyond what could be reasonably demanded of all persons, and indeed was blatantly inconsistent with what Madison and Adams called "human nature."61 Indeed, from the perspective of the argument for universal toleration, the enforcement of such perfectionist ideals by the state would impose a factionalized moral view upon society that obfuscates the legitimating responsibility of the state to respect inalienable human rights and to pursue the public good. For example, the civic virtue of the ancients not only legitimated slavery and the subjugation of women (in contrast, for example, to the Founders' clear unease with the harsh political realities that perpetuated slavery in the new republic ${ }^{62}$ ), but also, rampant imperialism for the sole purpose of military adventure and glory. ${ }^{63}$ Thus, the civic virtues of classical republicanism were, as both Montesquieu ${ }^{64}$ and Hume ${ }^{65}$ had recognized, masks for political manipulation and tyranny.

The Founders' skepticism about classical virtue reflected the larger skepticism of the argument for universal toleration and the egalitarian ethic of equal respect that it made possible. But, consistent with these skepticisms, the Founders believed, like Locke and Bayle, in ethically valid principles, and they perceived their constructivist task in 1787 to be mobilizing human nature, as they had come to understand it, in the service of such objective principles of equal justice under law. ${ }^{66}$ While their fundamental political theory of legitimacy was, of course, familiarly Lockean, ${ }^{67}$ their innovativeness came in the way they constructed political forms (federalism, the separation of powers, judicial review premised on inalienable rights of the person immune from political bargaining) that were self-consciously designed to reflect their serious skepticism about heroic political virtue.

This skepticism took two principal forms: First, the fact that many political arguments will be motivated by sectarian commitments to a person, group

61. Madison writes: "[W]hat is government itself but the greatest of all reflections on human nature?" The Federalist No. 51, at 349 (J. Madison) (J. Cooke ed. 1961). John Adams writes of Sparta: "Human nature perished under this frigid system of national and family pride." $4 \mathrm{C}$. ADAMS, The Works of John Adams, supra note 9, at 554.

62. See, e.g., Storing, Slavery and the Moral Foundations of the American Republic, in R. HoRwITz, THE Moral Foundations of the American Republic $313-32$ (1986). But see Finkelman, Slavery and the Constitutional Convention: Making a Covenant with Death, in R. BeEman, S. Botein \& E. CarTer, Beyond CONFEDERATION 188 (1987).

63. See M. Finley, Politics in the Ancient World, in Democracy ANCIEnt and Modern, supra note 12, at 87 .

64. T. Pangle, Montesquieu's Philosophy of Liberalism 48-106 (1973); J. Shklar, Ordinary VICES 33, 196-97 (1984).

65. See, e.g., Moore, Hume's Political Science and the Classical Republican Tradition, 10 CAN. J. Pol. ScI. 809 (1977); D. Miller, Philosophy and Ideology in Hume's Political Thought $121,150-51$ (1981).

66. See, e.g., The Federalist No. 10 \& 51, at 56, 347 (J. Madison) (J. Cooke ed. 1961).

67. At the Pennsylvania ratifying convention, a leading Founder, James Wilson, characterized the provenance of the American theory and practice of constitutional legitimacy in the following terms: "The great and penetrating mind of Locke seems to be the only one that pointed towards even the theory of this great truth." See 2 M. JENSEN, supra note 24, at 472. On the Lockean theory of political legitimacy, see D. Richards, Toleration, supra note 6, at 98-102; see generally R. AshCraft, Revolutionary Politics and Locke's "Two Treatises of Government" (1986). 
interests, or idea (Madison's Humean theory of faction ${ }^{68}$ ) makes it impossible for people to give fair weight to the rights and interests of those outside their sectarian circle. Second, the fact that aspirations for political power are primarily motivated by a desire for admiration and reputation (John Adams' theory of fame ${ }^{69}$ ) makes it doubtful that people are actually selflessly acting for the good of the state. Both of these aspects of political psychology were assumed by the Founders, and taken seriously as central political motivations that would have to be channeled in ways more likely to achieve the objective ends of republican justice. The theory of representation underlying the federal system, for example, was designed precisely, so Madison argued, ${ }^{70}$ to detoxify faction in the service of republican justice; and the theory of separation of powers, including an independent and powerful executive, was used by John Adams in the framing of the Massachusetts Constitution ${ }^{71}$ (a great influence on the Framers ${ }^{72}$ ) as a means of harnessing competition as a prod to republican justice. ${ }^{73}$

Neither Madison nor Adams denied that a sense of justice exists, or that people often conscientiously act on it, or that such a sense of justice must play an important role both in the people and leadership of constitutional republicanism. To the contrary, "[r]epublican government presupposes the existence of these qualities in a higher degree than any other form," 74 and construes its constitutional tasks "to obtain for rulers, men who possess [the] most wisdom to discern, and [the] most virtue to pursue the common good of the society; and ... to take the most effectual precautions for keeping them virtuous."75 As previously stated, the Founders were not moral skeptics, but they were skeptics about political psychology, and they perceived their constitutional task as framing the powers and responsibilities of government in such a way as to channel the political psychology of faction and competition in ways likely to support the results that republican justice requires.

Both of these assumptions about political psychology bespeak a skeptical distrust, consistent with the argument for universal toleration, of the distortions of moral judgment by political power, whether by economic interests, sectarian self-righteousness, or willful pride. The lesson to be

68. See The Federalist No. 10, supra note 9, at 57 (J. Madison). Madison takes the theory of faction from the political psychology of David Hume. See D. HumE, Of the First Principles of Government, in Essays Moral, Political and Literary 30 (1963); D. Adair, Fame and the Founding Fathers 75-106 (1974).

69. For Adams' most extended philosophical explication of this theory, see J. ADAms Discourses on Davila, in 6 C. Adams, The Works of John Adams 232-81 (1851). See generally J. Schutz \& D. Adair, The SPUR of Fame (1980); D. Adair, supra note 68, at 20-25.

70. The Federalist No. 10, supra note 9, at 56-65 (J. Madison).

71. For John Adams' work on the framing of the Massachusetts Constitution, see 4 C. AdAMs, The Works of John Adams, supra note 9, at 213-67. For an important political essay supportive of the theory of constitutionalism that was to flower in Adams' drafting of the Massachusetts Constitution of 1780 , see The Essex Result, in 1 C. Hyneman \& D. Lutz, American Political Writing DURING THE Founding ERA 1760-1805, 480-522 (1983).

72. See, e.g., The Federalist No. 69, at 464 (J. Madison) (J. Cooke ed. 1961).

73. See The Federal.ist No. 51, at 347-53 (J. Madison) (J. Cooke ed. 1961).

74. See The Federalist No. 56, at 378-83 (J. Madison) (J. Cooke ed. 1961).

75. See The Federalist No. 57, at 384-90 (J. Madison) (J. Cooke ed. 1961). 
learned from a sober reading of political history, including that of classical republicanism, was-the Founders argued ${ }^{76}$ - the need to break the easy link between factionalized moral and political judgment and political power institutionally. The most substantive and direct constitutional attempt to break this linkage was the adoption of the first amendment.

The doctrinal point-pervasive both in the law of religious liberty and free speech-may be put in terms of the argument for universal toleration discussed earlier, an argument that the protections of the first amendment self-consciously assume. ${ }^{77}$ The argument for universal toleration distrusts the power of the state to make impartial judgments about the scope of reasonable decisions in the formation, expression, and revision of one's religious conscience and the moral and political judgments of ultimate value. In essence, censorious state judgments in this arena rest on the fallacy of the Augustinian argument for religious persecution: Judgments about the worthlessness of beliefs, made from the censor's perspective of sectarian ideological commitments, are fallaciously assumed to justify the inference of irrationally self-destructive madness and harm to self and others and, on that ground, of political repression.

The principle of universal toleration was generalized into a constitutional principle that is a prophylaxis against this fallacy: Namely, judgments of the state about the unreasonableness of beliefs of conscience or the irrational worthlessness of speech, precisely because they are not content neutral, ${ }^{78}$ cannot justify the abridgement of the liberty to form, express, or revise conscience. Abridgement of such beliefs or speech cannot be justified on such essentially sectarian grounds, but only in terms of some conception of imminent secular harms, the violation of what Locke called "civil interests," which he thus defined: "Civil interest I call life, liberty, health, and indolency of body; and the possession of outward things, such as money, lands, houses, furniture, and the like."79 Secular harms, understood as the violation of such interests, assume a commonly understood metric of general goods that define a constitutionally reasonable benchmark of neutrality among the pluralistically disparate visions of the good life to which reasonable persons may commit themselves, including their more ultimate religious or philosophical perspectives. ${ }^{80}$ Accordingly, the American constitutional protections of both conscience and speech forbid any non-neutral censorious judgments, and allow the state to exert its regulatory power in these areas

76. See, e.g., The Federalist No. 10, supra note 9, at 56 ( J. Madison); J. Adams, A Defence, in $4 \mathrm{C}$. Adams, The Works of John Adams, supra note 9, at 283-98; J. Adams, Thoughts on Government, in 4 C. ADAMS, supra note 9, at 193-200.

77. See generally D. Richards, Toleration, supra note 6.

78. Cf. Stone, Content-Neutral Restrictions, 54 U. ChI. L. Rev. 46 (1987).

79. J. Locke, $A$ Letter Concerning Toleration, supra note 46, at 9-10.

80. See Rawls, Social Uitity and Primary Goods, in Utilitarianism and Beyond (A. Sen \& B. Williams eds. 1982). 
only to the extent supported by compelling secular state interests, that is, the clear and present danger of secular harms. ${ }^{81}$

The moral nerve of these constitutional doctrines is protection of autonomy in a stronger sense than appears elsewhere in the constitutional design. The point is not merely to insure that an individual has the capacity, liberty, and opportunity to act in a manner consistent with the criminal law, ${ }^{82}$ but to offer protection for the exercise of reasonable judgment independent of the conventional judgments of reasonableness embodied in law and public policy. Autonomy, in this sense, protects not the individual's reasonable capacities to conform to law, but his ability, as an independent person, reasonably to reflect on the ultimate values of life. ${ }^{83}$ Autonomy at this juncture is clearly close to the moral nerve of Kantian constructivist legislation in the kingdom of ends, for the value in law here protected is precisely the capacity for moral independence that Kant took to be foundational to the distinctive moral status of persons. ${ }^{84}$

Full autonomy, as a value of the first amendment, does not, however, require the full Kantian machinery of nomenal and phenomenal worlds and causal indeterminism. ${ }^{85}$ The political point is not that moral persons create themselves ex nihilo, or are independent of all causal law or explanation; indeed, the Founders assumed just the opposite, an empirically grounded law of political psychology (for example, the theory of faction). Rather, the point is that persons not only have a rational capacity to reflect on and order their own desires and appetites over time and to act on reasons supplied by the state or conventional authority, but they also possess a higher-order capacity to reflect on the nature, weight, and authority of such reasons. That each and every person has this ultimate normative authority is the moral foundation for the only kind of sovereignty consistent with constitutional liberalism, popular sovereignty. ${ }^{86}$

The value in law of full autonomy is not a metaphysical one, nor does it arise in a vacuum of atomistically ahistorical self-creation. ${ }^{87}$ Contextually, as we have seen, full autonomy arose as an important political issue only when pluralistic moral perspectives became a live issue in the Reformation, when the traditional role of the state in the enforcement of sectarian value was subjected to searching criticism for inhibiting the expression of any 227.

81. For fuller discussion of these principles, see D. Richards, Toleration, supra note 6, at 178 -

82. See generally H. Hart, Punishment and Responsibility (1968).

83. For a general, recent treatment of these values, see L. Haworth, Autonomy (1986).

84. Kant expressed the relationship between ethical principles and autonomy as the analyticity of the principle of autonomy in the concept of morality in I. KANT, Foundation OF THE METAPHYSICS of Morals 59 (L. Beck trans. 1959). Cf. Rawls, Kantian Constructivism in Moral Theory, 77 J. PHIL. 515 (1980) (reformulation of Kant's conception of sovereignty in the kingdom of ends in terms of respect for each person's higher-order moral powers of rationality and reasonableness).

85. For pertinent commentary on these aspects of Kant's critical philosophy, see generally $S$. KORNER, KANT (1955).

86. See D. Richards, Toleration, supra note 6, at 38-41, 98-102. Cf. J. Wilson, Lectures on Law, in 1 The Works of James Wilson 168-96 (R. McCloskey ed. 1967).

87. See generally Rawls, Kantian Constructivism in Moral Theory, supra note 84. 
philosophical view that was contrary to sectarian orthodoxy. ${ }^{88}$ The point is not that sectarian orthodoxy was irrational or even non-rational (often it contained deep wisdom), but that it undermined its own intellectual integrity by shutting out alternative viewpoints.

It is no philosophical accident that Locke framed the argument for universal toleration in terms of constraints on enforceable public morality. The public morality enforceable through the criminal law must, in this view, be limited to the minimal standards of protection that can be reasonably enforced on persons with incommensurably diverse ultimate theories of value in living a good and ethical life. Correlatively, Locke makes the point, as did Jefferson, ${ }^{89}$ expressly in the terms of the harm principle. The state may not, for example, forbid killing a calf (in contrast to a child) in one's religious rituals, "for no injury is thereby done to anyone, no prejudice to another man's goods."90 John Stuart Mill's later articulation of the harm principle depends for its force not on doctrinal utilitarianism (as Mill believed), but on this argument, which is, as has been suggested, best understood in Kantian terms. From the Kantian perspective, the scope of enforceable public morality cannot extend to conduct whose condemnation rests on sectarian grounds not reasonably justifiable in terms of the protection of general goods. ${ }^{91}$

\section{V \\ Spheres of Privacy and the Harm Principle}

The constitutional guarantees of full autonomy were thus directed at a concrete historical problem, namely, the degree to which the state's enforcement of sectarian values had compromised the practical ethics of equal respect required for republican constitutionalism. Such constitutionalism rejected the elitist perfectionism of classical republicanism precisely because the latter's factionalized insularity failed to acknowledge, let alone take seriously, the inalienable rights that Richard Price correctly understood to be motivated by values of self-government fundamental to the American revolutionary and constitutional enterprise of republican government. The guarantees of the first amendment protect persons from the enforcement of factionalized conceptions of conscience and speech. This protection is necessary to prevent the infringement of the liberties of conscience and speech, which are basic to the notion that individuals are self-governing moral and political agents. This makes possible respect for individual rights that are the essence of republican constitutionalism.

88. See id. at 515 .

89. Jefferson observes: "The legitimate powers of government extend to such acts only as are injurious to others. But it does no injury for my neighbor to say there are twenty gods, or no god. It neither picks my pocket nor breaks my leg." T. JefFerson, Notes on the State of Virginia 159 (W. Peden ed. 1955).

90. J. LOCKE, A Letter Concerning Toleration, supra note 46.

91. For further defense of this position, see generally Richards, Kantian Ethics and the Harm Principle: A Reply to John Finnis, 87 Colum. L. Rev. 457 (1987). 
Self-government is not, in this sense, autarkic. Persons govern their lives by standards they take and adapt from the available public culture, and often do so as members of sub-communities of the larger culture, cultivating and elaborating distinctive values within their sub-community in contrast to alternative values available in other sub-communities of the larger society. Full autonomy as a basic value in self-government assumes these facts, and remits to each person, rather than to the state, the ultimate choice as to which standards best embody his values.

Persons under such a constitutional regime of full autonomy have responsibility for defining their goals; indeed, it is that responsibility, more than any other, that makes them self-governing agents. The resulting conception of constitutional government thus views voting rights and participation not as ends in themselves, but as instrumental to a larger conception of self-government that is not exclusively or even primarily political in nature.

Now we can see why liberal constitutional democracy incorporates as its basis a conception of self-government quite foreign to classical republicanism. In the classical republican tradition, Pericles denied that anyone could have any business outside politics. Liberalism, in contrast, does not regard democratic politics as the only forum for self-government, but as one of many forums whose legitimacy depends on appropriate respect for the integrity of other spheres of self-government through which people express their nature as self-governing moral agents in all aspects of life. Such spheres of selfgovernment are private in the sense that they enjoy, within limits, immunity from state power. The immunity of conscience and speech from state censorious judgments required by the principles of the first amendment is one example. ${ }^{92}$ Such spheres of self-government enable persons to take responsibility for those spheres of activity classically defined as inalienable rights of the person. These are the rights that cannot justly be surrendered to any state and against which the legitimacy of state power must accordingly be tested. State power that abridges these rights is, by definition, illegitimate. ${ }^{93}$ The constructivist problem of liberal constitutionalism was to design a constitutional system that, on the one hand, immunized these spheres of selfgovernment from political bargaining and, on the other hand, mobilized the power of the state to pursue the public good in those areas justly surrendered to the state. ${ }^{94}$

92. These various senses of "privacy" at ștake are explored in D. Richards, Toleration, supra note 6 , at $242-44$.

93. See id. at 67-102.

94. Arguments of principle and arguments of policy roughly capture the distinction that the Founders contemplated and that the interpretation of the constitutional system clearly contemplates (for example, the arguments of principle central to the first amendment and the equal protection clause of the fourteenth amendment versus the arguments or policy, characteristic of debates over federalism). That arguments over the scope of federal power would be arguments of policy, best addressed to legislative discretion, was the clear view of several leading Founders, most notably James Wilson. Wilson distinguished, both at the Constitutional Convention and the Pennsylvania ratifying convention, civil liberty from federal liberty. See, e.g., I M. Farrand, Records of the 
Because this conception of voting rights and participation is in service of this more structurally complex conception of legitimate government, voting rights occupy a different moral space in liberal constitutionalism than they did in classical republicanism. Voting rights, for example, were thought of by the Founders as an instrumental means to ensure that the state respects inalienable rights and pursues the public good. Voting rights were therefore so structured and distributed to pursue these ends. ${ }^{95}$ The politics of mass participation of classical republicanism so flouted inalienable rights that Madison identified "the true distinction between [classical republican governments] and the American Governments"96 as being the latter's repudiation of a participatory politics that would unleash what Alexander Hamilton called the "demon of faction." 97

Because voting rights do not properly extend to the abridgement of inalienable rights, it is equally consistent with the liberal conception of voting rights that the scope of democratic political bargaining should not be extended to this sphere. The extraordinary vitality of judicial review in the United States today depends on these distinctive normative commitments of liberal constitutionalism. The central role of the judiciary today is largely that of monitoring the scope of political bargaining to ensure that inalienable rights are not infringed. ${ }^{98}$

This latter conception explains the derivation and elaboration in American constitutional law of the much controverted constitutional right to privacy.99 This right focuses on the interpretive elaboration and vindication in contemporary circumstances of an inalienable right of the person explicitly assumed by the Founders, namely, the right of intimate association, of which marriage was the paradigm in 1791.100 Various clauses of the Constitution,

Federal Convention of 1787, at 166 (1911); 2 M. Jensen, supra note 24, at 346-47. Civil liberties included many of the rights guaranteed by state bills of rights and, as such, subject to arguments of principle. But federal liberties identified the public policy purposes of government granted to the federal government because state regulation thereof-though affecting other states-had neither effectively realized their benefits, nor fairly distributed their benefits and burdens. The scope and distribution of such federal liberties were, Wilson argued, a highly discretionary judgment of policy remitted under the Constitution to the judgment of a representative Congress. The distinction between arguments of principle and policy is a prominent feature of the jurisprudence of Ronald Dworkin. See generally R. Dworkin, Taking Rights Seriously (1977); R. Dworkin, A MatTer of Principle (1985); R. DWorkin, Law's Empire (1986).

95. Madison argues to this effect in The Federalist No. 10, supra note 9, at 56 ( $\mathrm{J}$. Madison).

96. See The Federalist No. 63, at 428 (J. Madison) (J. Cooke ed. 1961).

97. See The Federalist No. 65, at 444 (A. Hamilton) (J. Cooke ed. 1961).

98. See D. Richards, Toleration, supra note 6, at 290-92.

99. See, e.g., Griswold v. Connecticut, 381 U.S. 479, 483 (1965) (the right to purchase contraceptives protected); Roe v. Wade, 410 U.S. 113, 152 (1973) (right to an abortion protected); Bowers v. Hardwick, 106 S. Ct. 2841,2843 (1986) (consensual homosexual behavior unprotected). These cases trace the development of the constitutional right to privacy over the last 22 years. They were not uncontroversial. For the controversy over Roe, see generally Ely, The Wages of Crying IVolf: $A$ Comment on Roe v. Wade, 82 Yal. L.J. 920 (1974). For controversy over Bowers, see generally Richards, Constitutional Legitimacy and Constitutional Privacy, 61 N.Y.U. L. Rev., 800 (1986).

100. The Founders assumed that inalienable human rights included what Hutcheson called "the natural right each one has to enter into the matrimonial relation with anyone who consents." $F$. Hutcheson, A System of Moral Philosophy 299 (P. McReynolds ed. 1969). Indeed, relevant historical materials suggest that the right may be more abstractly stated. For example, John 
including the ninth amendment, assume that unenumerated basic human rights will be enforced on a par with enumerated rights. ${ }^{101}$ The right of intimate association counts as one such unenumerated right, because intimate personal life is one of the spheres of self-government, like conscience and speech, that republican principles reserve from state power. ${ }^{102}$ Republican constitutionalism envisions intimate personal life as a sphere of selfgovernment on a par with conscience and speech precisely because the choices of personal life, like those of conscience and speech, engage both the head and heart in a way essential to the independent exercise of our moral powers. They identify the communities, or the need to construct communities, through which free persons may define and implement a life that engages their ultimate personal and ethical values. ${ }^{103}$

Republican constitutionalism thus assumes that choices of personal life occupy the same moral space of sovereign independence from state power as do choices of conscience and speech, because the independence of all these choices preserves the equal moral sovereignty of each and every person subject to state power that alone legitimates the power of the state. ${ }^{104}$ The Founders rejected the ethical perfectionism of classical republicanism because it imposed factionalized values that flouted the respect for rights and the public good fundamental to republican legitimacy and debased the competence of persons to make judgments about their personal values. The

Witherspoon, whose lectures Madison attended at Princeton, followed Hutcheson in listing as a basic human and natural right a "right to associate, if he so incline, with any person or persons, whom he can persuade (not force)-under this is contained the right to marriage." J. WITHERSPOON, LeCtures on Moral Philosophy 123 (J. Scott ed. 1982). Accordingly, Oliver Ellsworth, a leading commentator writing in support of the ratification of the Constitution, rebutted the anti-federalist argument that the 1787 Constitution failed to explictly protect the liberty of the press by noting that this right, like many other fundamental rights (including the right to marry) was clearly reserved from state power: "Nor is liberty of conscience, or of matrimony, or of burial of the dead; it is enough that congress have no power to prohibit either, and can have no temptation." O. EllsworTh, A Landholder VI, reprinted in $14 \mathrm{~J}$. Kaminski \& G. Saladino, Documentary History of the Ratification of the Constitution 401 (1976). Earlier, Ellsworth wrote of "a matter more sacred than all the property in the world, the disposal of children." Id. at 141. Similarly, leading statesmen at the state conventions ratifying the Constitution, both for and against adoption, assumed that the Constitution could not interfere in the domestic sphere. Thus, Alexander Hamilton denied that federal power does or could "penetrate the recesses of domestic life, and control, in all respects, the private conduct of individuals." 2 J. Ell.iot, Debates in the Several State Conventions 268 (1836). Patrick Henry of Virginia spoke of the core of our rights to liberty as the sphere where a person "enjoys the fruits of his labor, under his own fig-tree, with his wife and children around him, in peace and security." $3 \mathrm{~J}$. Elliot, Debates in the Several State Conventions 54 (1836). It is striking that the rhetoric of reserved rights both of leading proponents (Hamilton) and opponents (Henry) of adoption of the Constitution converged on the private sphere of domestic life.

101. John Hart Ely, for example, concedes that much of the text of the Constitution itself contemplated the inference of fundamental rights not specified in the Bill of Rights, for example, the privileges and immunities clause of the fourteenth amendment, adapted from the comparable clause in Article IV. See J. Ely, Democracy and Distrust 22-30 (1980).

102. For a general defense of the right to intimate association as an unenumerated right protected by American constitutional tradition, see generally Karst, The Freedom of Intimate Association, 89 YALE L.J. 624 (1980).

103. See D. Richards, Toleration, supra note 6 , at 242-54.

104. See id. at 39-41, 98-102. For an exploration of the various senses of "privacy" at stake here, see id. at $242-44$. 
constitutional doctrines of both religious liberty and free speech have elaborated upon this theme in their rejection of the censorship of either conscience or speech on grounds that reflect sectarian values. The protection of the right to privacy calls for no less. Otherwise, the right to privacy will be trivialized and regulated according to the lowest common denominator of majoritarian taste. ${ }^{105}$

Accordingly, coercive constraints on the exercise of the right to privacy have become constitutionally suspect when, in contemporary circumstances, they can no longer be justified to society in the non-sectarian terms that constitutional principles require. Prohibition of the sale and use of contraceptives clearly cannot be justified in the required way, and it is therefore natural that the constitutional right to privacy was first elaborated to strike down such laws. ${ }^{106}$

Later elaborations of the constitutional right to privacy, such as its expansion to cover abortion and its failure to cover consensual adult homosexual behavior, ${ }^{107}$ are much more controversial. ${ }^{108}$ This author certainly will not defend all the work of the Supreme Court in this area, in particular, the Court's ill-considered and incoherent refusal to extend constitutional protection to consensual adult homosexual behavior. ${ }^{109}$ But the constitutional right to privacy is clearly a correct attempt to protect the sphere of moral self-government surrounding intimate personal life from the tyrannies of majoritarian values.

In the context of this argument, the harm principle derives not from utilitarianism, but from a rights-based conception of the essential spheres of self-governing moral independence. It is therefore, in principle, wholly irrelevant how widespread sectarian perspectives on the worth of conscience, speech, or lifestyle might be, or how much the pleasure of majoritarian solidarity about such perspectives might, on utilitarian grounds, outweigh the pains of despised outcasts from such perspectives. The harm principle does not occupy the moral space subject to such utilitarian aggregation and the political bargaining that is its vehicle, and thus Mill was correct, albeit not on utilitarian grounds, to insist:

If all mankind minus one, were of one opinion, and only one person were of the contrary opinion, mankind would be no more justified in silencing that one person, than he, if he had the power, would be justified in silencing mankind. ${ }^{110}$

The point is that no teleological political theory can plausibly explain without circularity the power of Mill's intuitions or the principles of American constitutional law that support them.

105. For further amplification, see id. at 231-54.

106. Griswold v. Connecticut, 381 U.S. 479, 483 (1965). For further discussion, see D. Richards, Toleration, supra note 6 , at 256-61.

107. Roe v. Wade, 410 U.S. 113,152 (1973).

108. Bowers v. Hardwick, 106 S. Ct. 2841,2843 (1986).

109. See generally Richards, Constitutional Legitimacy and Constitutional Privacy, supra note 99.

110. Mill, On Liberty, supra note 4, at 204. 
This author has therefore developed an alternative political theory, and shown how that theory emerges quite naturally as the best interpretation of the American constitutional tradition. That theory is, of course, deontological, in the sense that the relevant principles of political right (like equal liberty of conscience, or speech, or association) are not understood as justified by teleological aggregation in any sense, but as principles that enjoy, within the scope of their application, priority over aggregative considerations. Put bluntly, the strength of these principles is shown by the fact that they often apply even when aggregative arguments (for example, the pleasure of social solidarity) would require the contrary. Such arguments are usually expressed in American constitutional law as arguments framed as basic rights, and rights are, at least for Americans, trumps over majoritarian political bargaining. ${ }^{11}$ That practice is, as has been suggested, best interpreted in the terms of a deontological political theory of a Kantian sort, namely, that American constitutionalism is a constructivist exercise in liberal political theory, in which the state's legitimacy depends, inter alia, on its respect for equal liberties like conscience, speech, and association that enable people to retain their status as self-governing moral agents to whom the state is accountable.

The harm principle, thus understood, is a requirement that the abridgement of these liberties can only be justified in terms of a background theory of justice and a showing of compelling secular interests not themselves hostage to a factionalized perspective on human values. The proper interpretation of this requirement is often controversial, for people who fully accept its normative force may differ over how it applies in a particular case, notably, abortion. ${ }^{112}$ Furthermore, society's sense of whether or not the burden of justification is even in issue, let alone met, is contextually sensitive to changing understandings of background issues of fact and social and economic factors, including demographic shifts due to changing rates in mortality and morbidity in response to public health measures. The role of children in marriage and the family, for example, obviously changed due to the shift from a largely agrarian to an industrial society against a background of declining adult and infant mortality rates. Children play less of an economic role in an industrial society than they previously played on the farm, and having large numbers of them is less sensible when one knows that most will live to adulthood. Strong political requirements, supportive of having many children and even having children at all, might in the earlier period have appeared so clearly justified that no objection to them was plausible, since having many children served imperative economic necessities. In the later period, such requirements (for example, anti-contraception and

111. See, e.g., D. Dworkin, Taking Rights Seriously, supra note 94, at 92, 102, 139, 146, 169 , $177,191,199,269$.

112. For the view that the prohibition of abortion satisfies this neutrality demand, see Greenawalt, Religious Convictions and Lawmaking, $84 \mathrm{MICH}$. L. Rev. 352, 371 (1985). For the view that it does not, see D. Richards, Toleration, supra note 6, at 261-69. 
anti-homosexuality laws) can no longer be justified because they aggravate the problems of overpopulation. ${ }^{19}$ Accordingly, the constitutional right to privacy is naturally brought into play to question such laws ${ }^{114}$ in a way that would, in previous circumstances, have been unthinkable. Indeed, the very conception of rights and responsibilities in family life undergoes changes responsive to such shifts, as many traditional conceptions are subject to reassessment in terms of their continuing neutrality, ${ }^{15}$ including, of course, their consistency with emerging constitutional principles of gender equality. ${ }^{116}$

In one respect, the theory of the harm principle, proposed here, is less expansive than the form of the principle associated with John Stuart Mill.117 For Mill, all forms of criminalization must be assessed in terms of this principle; the author's proposal limits the force of the principle to cases where the state abridges certain basic rights of the person, to wit, rights of conscience, speech, and association.

It is, of course, often a matter of some controversy as to how far the conception of basic rights should be extended and thus the corresponding scope of the application of the harm principle. American constitutional law has shown little tendency, for example, to extend such protection to commercial sex or most forms of drug use, ${ }^{118}$ although arguments to this effect are by no means frivolous. ${ }^{119}$ If such conduct is not within the scope of a constitutionally protected right to privacy, presumably laws criminalizing such conduct should be subject to a less demanding burden of justification than the harm principle. Nonetheless, many such laws still may be subject to cogent criticism on the ground that they cause more social evil and injustice than they remedy. ${ }^{120}$

113. On the force of these arguments in shaping a new political consensus, see generally J. REED, The Birth Control Movement and American Society: From Private Vice to Public Virture (1978).

114. See D. Richards, Toleration, supra note 6, at 256-61 (contraception), 269-80 (homosexuality).

115. Cf. Schneider, State-Interest Analysis in Fourteenth-Amendment "Privacy" Law: An Essay on the Constitutionalization of Social Issues, Law \& Contemp. Probs., Winter 1988, at 79,97-1 18 (whose critical views about the current understanding of state-interest analysis reflect many of these concerns).

116. For a discussion of the changing modern constitutional doctrine of sexual equality, see generally Law, Rethinking Sex and the Constitution. 132 U. PA. L. REv. 955 (1984).

117. See generally J. MiLL, On Liberty, supra note 4.

118. But see Ravin v. State, 537 P.2d 494, 511 (Alaska 1975) (the use of small amounts of marijuana by adults in the home is protected by Alaska Constitution); People v. Woody, 61 Cal.2d 716, 719-28, 394 P.2d, 813, 814-16, 40 Cal. Rptr. 69, 72-74 (1964) (ban on the drug peyote unconstitutional as applied to use in bona fide religious practices by the Native American Church).

119. See D. Richards, Sex, Drugs, Death, supra note 6, at 84-153 (commercial sex), 157-212 (drug use).

120. See id. Heroin may be a special case. See generally J. Kaplan, The Hardest Drug (1983) (on the difficulty of using any method short of prohibitionist policy to control heroin). But cf. A. Trebach, The Heroin Solution (1982) (regulatory, not prohibitionist, alternatives for control of heroin defended). 


\section{VI \\ Against Perfectionist Theories of Virtue and Vice}

The sphere of morally independent self-government is often at peril when popular moral objections to an action or way of life take the form of perfectionist argument. Arguably, a woman should not have an abortion, although carrying the child to term inflicts substantial personal and psychological costs on the woman, because the perfectionist ideal of selfsacrificing maternity is denigrated by abortions. ${ }^{121}$ Similarly, it might be argued that a homosexual should have no personal sexual life because that lifestyle flouts the ideal of traditional family life. ${ }^{122}$ As arguments for criminalization, such perfectionist arguments cannot be reasonably justified to the community at large, for arguments of this sort impose unreasonable sacrifices of well-being and personal happiness on the grounds of sectarian perceptions that many reasonable people reject. ${ }^{123}$

Consider-as a useful case study of the political implications of a selfconsciously articulated perfectionist moral theory-John Finnis' moral condemnation of contraceptives and homosexuality. ${ }^{124}$ The motivating idea in his condemnation of contraceptives is that their use insults the value of life (a child is not conceived) and the value of marital sexual friendship. But neither claim is clearly true, let alone reasonable. On what ground is contraception analogized to murder ${ }^{125}$ or to the mutilation of sexual love? Finnis' latter contention rests on a certain conception of the love of God, but there are many ways to view the value of sexual love and its relation to divine love, and many people are likely to find Finnis' diatribes of self-mutilation quite unbelievable and certainly not properly enforceable. For many persons, emancipated from traditional conceptions of mandatory gender and procreational roles, it is simply not unreasonable to believe, and act on the belief, that contraception not only violates no religious or moral duty, but makes possible the construction of new perspectives on the marital relationship-ones in which their sexual, personal, and ethical aims may be pursued on fairer terms than those allowed by the traditional marital relationship. ${ }^{26}$ The use of contraceptives does not degrade, nor does it mutilate; to the contrary, it has made it possible for women and men to make

121. See, e.g., K. Luker, Abortion and the Politics of Motherhood 126-57 (1984).

122. See generally R. Magnuson, Are Gay Rights Rights? (1985).

123. See D. Richards, Toleration, supra note 6, at 261, 280.

124. See Finnis, Personal Integrity, Sexual Morality, and Responsible Parenthood, 1 Anthropos: Rivista di Studi sulla Persona de la Familia 43, 48-49, 52-54 (1985). See generally Finnis, Legal Enforcement of "Duties to Oneself": Kant v. Neo-Kantians, 87 Colum. L. Rev. 433 (1987) (homosexuality). Finnis' views are explored at greater length in Richards, Kantian Ethics and the Harm Principle: A Reply to John Finnis, supra note 91 .

125. Of the emission of semen apart from procreation in marriage, Thomas Aquinas wrote: " $[A] f$ ter the sin of homicide whereby a human nature already in existence is destroyed, this type of sin appears to take next place, for by it the generation of human nature is precluded." T. AQuiNAS, On the Truth of the Catholic Faith: Summa Contra Gentiles 146 (V. Bourke trans. 1956).

126. See generally J. REED, supra note 113. 
moral judgments in defining fairer and more humane perspectives of the marital relationship.

Finnis' condemnation of consensual adult homosexual relations is no less unreasonable as a basis for criminalization than his condemnation of contraceptives. His picture of homosexuality as "the eighties gaybar/bathhouse, in which lust courts even homicide and self-destruction"127 is an uninformed stereotype of Manichean evil. This picture distorts the enormous range and diversity of relationships among homosexuals today. ${ }^{128}$ It falsely reduces all such relationships to one stereotype and even this stereotype is itself stereotypically shaped by the factionalized moral hatred that Finnis exemplifies which drives some homosexuals into anonymous and secretive encounters, the only lifestyle that can survive such hatred.129 The injustice of Finnis' characterization of homosexuality is manifest in the way he makes oblique reference to the AIDS health crisis. He suggests that the tragedy was self-willed when in fact the disease developed long before the relevant subclass of homosexual men knew or had reason to know that certain forms of homosexual relations led to the spread of the disease and thus before they could take reasonable preventive steps. ${ }^{130} \mathrm{He}$ also fails to take seriously the role of criminalization and moral stigma in increasing health risks. ${ }^{131}$ But Finnis is not concerned with making elementary distinctions or just observations about the diversities of homosexual life, or even to get the facts straight about this tragedy without villains. Rather, he frames moral assessment in the terms best designed to fit his inflexible stereotypes, thus indulging ignorance and intolerance, blaming the victim in a way that gratuitously insults moral innocence.

Finnis' picture of the vice of homosexuality should be compared with his contrasting picture of virtue: the traditional marriage relationship without use of contraceptives or abortion services, in which sexuality, friendship, and caring are wedded into a harmonious whole. That idealized picture is the sort of perfectionist value that Finnis believes fundamental to ethical reasoning, ${ }^{132}$ but Finnis' interpretation of his general goods shows the grave internal flaws

127. Finnis, Legal Enforcement of "Duties to Oneself," supra note 124, at 445.

128. See generally A. Bell \& M. Weinberg, Homosexualities: A Study of Diversity Among Men and Women (1978) [hereinafter Homosexualities]; A. Bell, M. Weinberg \& S. Hammersmith, Sexual Preference: Its Development in Men and Women 193-211 (1981); P. Blumstein \& P. Schwartz, American Couples 319-24 (1983); W. Masters \& V. Johnson, Homosexuality in Perspective 226-31, 403-11 (1979).

129. See, e.g., A. Bell \& M. Weinberg, Homosexualities, supra note 128, at 81-102; M. Hoffman, The Gay World 164-77 (1968); L. Humphreys, Tearoom Trade 1-15 (1970).

130. See Institute of Medicine, National Academy of Sciences, Mobilizing Against Aids 2 (1986). Indeed, once the nature of the transmission of the disease became widely known, homosexual men changed their sexual activities. Id. at 90-93.

131. See Note, The Constitutionality of Laws Forbidding Private Homosexual Conduct, 72 Mich. L. Rev. $1613,1632-33$ (1974). Criminalization and larger patterns of discrimination also render difficult the formation of the kinds of stable relationships which could both minimize health risks and humanely deal with health problems when they occur. See Mohr, AIDS, Gay Life, State Coercion, 6 Raritan 38 (1986).

132. See generally J. Finnis, Natural Law and Natural Rights (1980); J. Finnis, Fundamentals of Ethics (1983). 
of this picture as a standard for the enforcement of law. Finnis interprets that idealized picture in a way that many would reasonably reject as a stereotypical distortion. He imputes to marital relationships a certain kind of virtue that they often lack, and parodies any form of non-marital intimate relationship (including homosexual relationships) as lacking a virtue which they often have.

Consider a homosexual couple whose relationship endures over many years. All of the elements that Finnis attributes to conventional marriage may flourish there: sexual transcendence, intimate friendship, understanding and mutual support, caring for one another, and the range of interests that such a relationship fructifies. It is false to claim that such relationships are internally flawed and it distorts reality to fail to mark the genuine moral continuities in the virtues of personal relationships conventionally marital and unconventionally non-marital. ${ }^{133}$

How is this kind of self-willed moral blindness to be understood? The answer lies in two distinct strands of such perfectionist thought: the exoteric strand that writes for a broad secular academic audience ${ }^{134}$ and the esoteric strand that writes for a narrow audience. ${ }^{135}$ The exoteric writings emphasize highly abstract general goods that might appeal to reasonable people from diverse religious and philosophical backgrounds. ${ }^{136}$ In contrast, the esoteric writings elaborate a sectarian interpretation of how these goods are understood and weighed. ${ }^{137}$

The esoteric writings lack the reasonable tone and appeal of the exoteric writings in large part because they are more rigid and forthright about the full range of Finnis' concept of "mutilated sexual activity." 138 These esoteric writings are, even on their own sectarian terms, remarkably free of any close attention to history, to facts, or to ethically sensitive concern for persons as individuals. This can be seen by comparing Finnis' arguments to those of his coreligionists who take objection on such grounds to the traditional religious condemnation of both contraception ${ }^{139}$ and consensual homosexual behavior. ${ }^{140}$ From this perspective, Finnis' appeal to self-evidence will appear reasonable only to the astigmatism of a now embattled conception of traditional sectarian commitments, concerned to hold its ground against

133. See genetally P. Blumstein \& P. Schwartz, American Couples, supra note 128.

134. See generally J. Finnis, Natural LaW, supra note 132.

135. See generally Finnis Personal Integrity Sexual Morality, and Responsible Parenthood, supra note 124.

136. See generally J. Finnis, Natural LaW supra note 132.

137. This includes a defense of Papal writings on the moral theology of permissible birth control. See Finnis, Personal Integrity Sexual Morality, and Responsible Parenthood, supra note 124, at 48-49.

138. See id. at 54. Finnis thus condemns masturbation, id. at 43, 46-47; adultery. id. at 47; fornication, id. ; contraceptive use, id. at 48-49, 52-54; consensual adult homosexual relations, id. at 47. Additonally, Finnis condemns abortion, J. FinNis, Natural Law, supra note 132, at 117; drug addition, id. at 222; and voluntary decisions to die, id. at 110.

139. See, e.g., J. Noonan, Contraception: a History of Its Treatment by the Catholic Theologians and Canonists (1965).

140. See generally J. Boswell, Christianity, Social Tolerance, and Homosexuality (1980); J. McNeill, The Church and the Homosexual (1976); D. Bailey, Homosexuality and the Western Christian Tradition (1955). 
subversive critical assessment from within. If such critical assessment leads other coreligionists to question and reject this "common sense," surely the community at large cannot justly be kept hostage to such views as the measure of coercive enforcement of public morality. Such theological views-however conscientiously held-cannot claim any larger political legitimacy as the just measure of criminal law in a liberal state. ${ }^{141}$

Finnis presumably sees the exoteric and esoteric writings as forming a reasonable unity, but he strategically shapes his exoteric writing so as not to emphasize the full range of his moral commitments. ${ }^{142}$ His exoteric strategy is to appeal to the traditional moral common sense of the community at large in areas in which he believes it is still open to reason; lost causes, like contraception and divorce, are thus not addressed. But Finnis' arguments must be viewed seriously as claims of principle, not as disingenuous political advocacy, for otherwise it will only be the political popularity of contraception and unpopularity of homosexuality that will decide these issues. Finnis' normative arguments rest on a form of perfectionism that many people in society at large reasonably reject because they regard Finnis' moral excellences as an unreasonably restrictive conception of acceptable human values. It is precisely because perfectionist theories of virtue and vice of this sort cannot reasonably be enforced on society at large that, as a matter of principle, liberal societies can no more justly criminalize consensual homosexual behavior than they can contraception.

Our examination of Finnis' perfectionism should give us pause regarding the revival of interest in perfectionist moral theories of virtue and vice along Aristotelian lines. 143 These theories are often not transparently motivated, in the way Finnis' theory is, by a sectarian agenda, and some of them so conceptualize full autonomy as the most important attribute of character that they reach conclusions often convergent with an autonomy-based ethics. ${ }^{144}$ But these theories are pervasively subject to the manipulative political use to

141. See generally Henkin, Morals and the Constitution: The Sin of Obscenity, 63 Colum. L. REv. 391 (1963) (Laws prohibiting consensual adult use of obscene materiais and consensual adult homosexuality, having a solely sectarian religious basis in contemporary circumstances, violate the anti-establishment clause of the first amendment.).

142. For example, in his article Legal Enforcement of "Duties of Oneself", supra note 124, Finnis deemphasizes his moral condemnation of contraception.

143. See, e.g., V. Haksar, Equality, Liberty, and Perfectionism supra note 23; A. Macintrre, supra note 8; B. Williams, Ethics and the Limits of Philosophy (1985); J. Raz, supra note 23.

144. See, e.g., sources cited supra note 143. Nonetheless, objection may be taken to such views on Kantian grounds. Kantian autonomy is a higher-order appeal to practical reason and to the highly abstract goods and resources consistent with this conception. It thus tries to avoid the controversial and often highly intuitionistic kinds and weights of goods to which perfectionists tend to appeal. See generally Rawls, Social Unity and Primary Goods, supra note 80. Kant's autonomy-based ethics does not, in contrast to perfectionism, regard autonomy as one perfectionist value among others, all of which must be consequentially maximized, but interprets equal respect for autonomy as the core of ethical thinking and interprets and weighs other goods by reference to it. The systematic structure of Kantian moral theory thus removes the intuitionistic interpretation and weighing of various excellences on which perfectionism depends. Even as moderate and balanced a perfectionist as Joseph Raz (see supra note 23) presents highly intuitionistic conceptions of excellences and their relative weights in a way that undermines the force of his broadly liberal conclusions. 
which Finnis puts them: the question-begging enlistment of the rhetoric of vice in the service of a now embattled conception of traditional morality.

There is good reason for us to be constitutionally suspicious of arguments for the legal enforcement of many forms of such perfectionism on the same ground that the Founders were suspicious. Such arguments are often fueled by factionalized conceptions of virtue and vice not reasonably justifiable to all persons as universally applicable and enforceable moral standards. Indeed, such factionalized perceptions blind people to the requirements of republican legitimacy, namely, that the state respect rights and pursue the public good. It was for this reason that the Founders, like Madison and Adams, were quite willing to find constitutional virtues where the classical republican tradition found only vice, and vice where it found virtue.

For example, for the Founders, the American absorption in commercial interests was not a republican vice, as it was for classical republican thought. Montesquieu and Hume had sharply contrasted the malign insularity and thirst for glory of the participatory republic of civic virtue ${ }^{145}$ with the way that commercial life and exchange under constitutional monarchies like Britain created incentives to peace and broader ties of reciprocal mutual cooperation among diverse peoples. ${ }^{146}$ Madison interpreted these views as arguments that an appropriately designed national framework of commercial exchange is essential to a civilized polity and conjoined them to the distinctively American (and Lockean) theme that one of the core rights to be reserved from state power is the right to freedom of conscience. Madison's two examples of faction were thus religious sectarianism and the "unequal distribution of property," 147 and he saw the representative structure of the federal system as an appropriate way to limit the effect of these forces and thus to heighten the liberating force of respect for rights both of conscience and property. ${ }^{148}$ For the Founders like Madison, the enumerated powers of the federal government to regulate interstate and international commerce were one with its lack of power over religion. State regulation of secular interests like commerce and no regulation of religion were mutually complementary and reenforcing ways of fostering the civilizing bonds of a community that treats persons as free and equal.

Conversely, the virtue of moral homogeneity in the city-states of classical republicanism was, in Madison's view, the key to their indulgence of the vice of faction, and why:

145. See, e.g., T. Pangle, supra note 64, at 48-106; Moore, supra note 65; D. Miller, Philosophy and Ideology in Hume's Political Thought 121, 150-51 (1981).

146. Compare T. Pangle, supra note 64, at 200-48 (such commerce is nothing short of world revolutionary), with D. Forbes, Hume's Philosophical Politics 296-98 (1975) (such commerce has been an essential cause of the growth of public liberty in civilized societies).

147. The Federalist No. 10, supra note 9, at 59 (J. Madison).

148. On the liberating force of capitalist commercial life in early America, see generally $\mathrm{J}$. Appleby, Capitalism and a New Social Order (1984). 
such Democracies have ever been spectacles of turbulence and contention; have ever been found incompatible with personal security, or the rights of property; and have in general been as short in their lives, as they have been violent in their deaths. ${ }^{149}$

Such moral homogeneity, in the service of the Aristotelian perfectionism of classical republicanism, was often factionalized and therefore unjustly oppressive. Consequently, the moral pluralism of a large nation with diverse sects and interests was not a vice, but a virtue to be used in the service of the paramount ends of republican government, respect for rights and the public good. ${ }^{150}$

In effect, the political theory of the United States Constitution urges skepticism about the politics of virtue and vice. Many of the vices under classical republicanism (for example, commercial competitiveness and moral pluralism) were, for the Founders, key ingredients of republican virtue precisely because they eroded the unrealistic insularity of perfectionist elitism. Correspondingly, many of the virtues of classical republicanism (for example, moral homogeneity) were often, at least when enforced on the community at large, constitutional vices. ${ }^{151}$

Society, therefore, has the best reasons to be skeptical about enforcing moral perfectionism on the community at large. Indeed, protection against such arguments is most needed in the defense of rights like the right to privacy, when persons have not had a fair cultural opportunity to participate as reasonable and equal members of the moral community in the definition of the moral standards now enforced against them.

Both women and homosexuals have clearly been afflicted by such immoral exclusion, and indeed have been denied the fair opportunity even to have an identity on terms of equal respect. The rhetoric of vice is so naturally invoked against their minimal claims to rights of reproductive and sexual autonomy because traditional morality has so ignored and denigrated their rights of moral personality, that any attempt to give value to their lives can be speciously but plausibly dismissed as "self-evidently" deficient in human good. Perfectionist theories of virtue and vice are the natural instruments of such unjust failures of moral imagination that feed on Manichean images immune to evidence or argument.

It would be constitutionally grotesque to allow such theories to be the measure of constitutional rights, ${ }^{152}$ for such views-precisely when most popular-bespeak the factionalized hatred of outcasts against which such rights are the prophylaxis. Liberal constitutionalism, of which the United States Constitution is a pathbreaking experimental exemplar, insists on the inalienable right to generate one's own personal ethical vision against the selfblinding claims of majoritarian moral factionalism. That right protects the

149. The Federalist No. 10, supra note 9, at 61 (J. Madison).

150. See The Federalist No. 10, supra note 9, at 56 (J. Madison).

151. Cf. J. SнкLAR, supra note 64, at 33, 196-97, 233-34 (The basis of constitutional government is a diffuse distrust of humanity, and is so designed to accommodate any self-interested population.).

152. See, e.g., Bowers v. Hardwick, 478 U.S. 86 (1986). For a criticism, see Richards, Constilutional Legitimacy and Constitutional Privacy, supra note 99. 
struggle for an authentic moral voice of groups traditionally silenced as moral and political heretics. Their heresy against traditional morality is what dignifies their claim of simple justice for the space-free of criminal penalty and its stigma-in which to define a moral identity adequate to give value and dignity to their communities and their lives.

\section{VII}

\section{ConClusion}

Liberal constitutionalism, in contrast to classical republicanism, does not celebrate political participation as an end in and of itself. Rather, liberal constitutionalism represents a more complex conception in which persons may themselves generate and pursue a moral framework that is either pointedly apolitical, not primarily political, or sharply critical of dominant moral conceptions embodied in law. Indeed, self-government, in the sense central to Lockean constitutionalism, achieves its fullest expression in what has been called full autonomy. This is made possible by a constitutional culture that restrains the power of the state from interfering with the practice and expression of values not acceptable to the majoritarian orthodoxy.

The constraints that liberalism thus places on the scope of the criminal law are not inconsistent with the play of perfectionist ideals in living a good and ethical life. Many liberals condemn courses of conduct that, in their view, fall short of an ideal life, although they would not, as a matter of liberal principle, criminalize such conduct; and they are often prepared to regulate conduct, including its advertising, that they would not criminally condemn. ${ }^{153}$ That attitude is not at all paradoxical, for it is indeed made possible by the insistence of liberalism on respect for full autonomy. ${ }^{154}$ It is because persons are constitutionally guaranteed such full autonomy that they bear so large a responsibility themselves to decide among the incommensurable ideals of a good life that flourish in a liberal society. The point of liberalism is neither that ideals are unimportant, nor that only life, liberty, and property are important. Rather, the idea is that persons must themselves give value to living, and that no single perfectionist theory of the proper uses of life, liberty, and property can be enforced on the community at large, usurping the moral liberty of the people.

It is fundamental to liberal constitutionalism that it must reject, as the Founders so clearly saw, the ethical perfectionism of classical republicanism. Liberal culture does not define ultimate value in democratic politics as political participation, for its most glorious achievements are its defense, on grounds of principle, of what classical republicanism made possible but then ruthlessly crushed-the critical and dissenting moral individualism of Socratic integrity.

153. See, e.g.. D. Richards, Sex, Drugs, Death, supra note 6, at 121-25, 189-95.

154. See generally Richards, Human Rights and Moral Ideals: An Essay on the Moral Theory of Liberalism, 5 Soc. Theory \& Prac. 461 (1980). 